Hugoye: Journal of Syriac Studies, Vol. 15.1, 7-20

(C) 2012 by Beth Mardutho: The Syriac Institute and Gorgias Press

\title{
KTABE MPASSQE:
}

\section{DISMEMBERED AND RECONSTITUTED SYRIAC AND CHRISTIAN PALESTINIAN ARAMAIC MANUSCRIPTS: SOME EXAMPLES, ANCIENT AND MODERN}

\author{
SEBASTIAN BROCK \\ UNIVERSITY OF OXFORD
}

As will be readily recognized, the title Ktabe mpassqe reflects the dire fate of the fifth-century Persian martyr commemorated on $27^{\text {th }}$ November, whose Martyr Acts have circulated widely in a number of different languages, besides Syriac. ${ }^{1}$ In the case of manuscripts, the instances in antiquity of dismemberment could fairly be described as a process of the recycling of parchment from older manuscripts, by erasing the original text and re-using the parchment for writing a new text, ${ }^{2}$ whereas in modern times it might just as well be designated vandalism (often carried out for

1 See the dossier in P. Devos, 'Le dossier hagiographique de saint Jacques l'Intercis', Analecta Bollandiana 71 (1953), pp.157-78.

2 The creation of Syriac palimpsests took place for the most part between the $9^{\text {th }}$ and $12^{\text {th }}$ centuries; for this in the British Library collection, see A.B. Schmidt, 'Syriac palimpsests in the British Library', in V. Somers (ed.), Palimpsestes et éditions de textes: les textes littéraires (Leuven, 2009), pp.161-186. The erased folios might sometimes be cut down to fit the requirement of a different size. 
the sake of the undertext in a palimpsest manuscript). ${ }^{3}$ The nature of the reconstitution is likewise different, depending on whether it occurred in ancient or in modern times: in ancient times, when special need arose, a text in frequent current use, notably the Gospels, was pieced together out of several different constituent manuscripts (which may well have already been themselves by then in a fragmentary state), whereas in modern times this reconstitution consists in the bringing together (whether or not physically) the constituent parts of manuscripts that have been broken up (at some earlier point in modern times) by unscrupulous visitors to monastery libraries, and which were subsequently scattered among libraries all over the world.

In this paper a selection of some striking examples, both ancient and modern, is offered, all taken from early manuscripts preserved over the centuries in two monastery libraries in Egypt, that of St Catherine's Monastery, Sinai, and that of Dayr al-Suryan, between Cairo and Alexandria.

\section{DISMEMBERED MANUSCRIPTS}

The first three examples concern manuscripts of St Catherine's Monastery where, in the late tenth century, the well-known Georgian scribe, Iovane Zosime, reused considerable quantities of folios from discarded Christian Palestinian Aramaic (CPA) manuscripts, seeing that parchment was evidently scarce. This was a period of considerable activity by Georgian monks in the Monastery, and at one point a Georgian monk - possibly Iovane Zosime himself, who came to St Catherine's from the Monastery of St Sabas, south of Jerusalem, at some time before 973 - must have been in charge of the library, since quire numbers have sometimes been added in Georgian letters to a number of Syriac manuscripts.

1. In the case of our first example it is necessary to begin with the modern dismemberment. The Georgian ms. 81 in Tsagareli's

${ }^{3}$ As G. Garitte observed. 'ce sont les textes syro-palestiniens sousjacents qui ont excité la convoitise d'orientalistes amateurs de raretés et d'inédits et les ont fait succomber à la tentation de soustraire le manuscrit à la bibliothèque du Sinai et à l'amputer de plusieurs de ses feuillets' (Bedi Kartlisa 23/4 [1967], pp.51-2). 
catalogue 4 (written by Iovane Zosime in 979) was subsequently taken from the monastery and broken up. For a long time the whereabouts of its various dismembered parts was not clear, but thanks to the researches of a number of scholars, ${ }^{5}$ their locations are now known: most of the palimpsest folios are today in the Schøyen Collection (Oslo; mss. 35, 36, 37), but a number are also to be found in St Petersburg (incorporated into ms. Syr. 16), and two further folios in Göttingen (Syr. 28).

Iovane Zosime re-used a large number of folios from several different older CPA manuscripts. At least five separate CPA mss. have been identified: three folios are from an Old Testament Lectionary; two Gospel Lectionaries are involved, with 14 folios preserved of one and 17 of the other, while no less than 100 folios contain extensive parts of Cyril of Jerusalem's Catecheses, and a further seven folios contain a text that has not yet been identified.

The CPA undertexts of the St Petersburg folios were published by J.P.N. Land in the fourth volume of his Anecdota Syriaca (1875), but are now for the most part available in an improved edition by C. Müller-Kessler and M. Sokoloff in their Corpus of Christian Palestinian Aramaic. ${ }^{6}$ The folios now in the Schøyen Collection were published by A. Desreumaux in his Codex Zosimi Rescriptus (1997), and independently also by Müller-Kessler and Sokoloff (who also include the Göttingen folios). (A few of the folios now in the Schøyen Collection had earlier been published by H. Duensing). ${ }^{7}$

4 There are four different catalogues covering the Georgian collection: by A. Tsagareli (1889), N. Marr (1940), G. Garitte (1956), and (for the 'New Finds') Z. Alexidze and others (2005); that by Tsagareli includes several mss. which were subsequently taken from the Monastery (including my second example); that by Garitte is the most detailed, but is confined to the patristic texts.

${ }^{5}$ Notable G. Garitte, 'Addendum: le codex sin. Géor. 81 (Tsag.)', Le Muséon 80 (1967), pp.90-92, and M. van Esbroeck, 'Les manuscrits de Jean Zosime Sin. 34 et Tsagareli 81', Bedi Kartlisa 39 (1981), pp.63-85.

${ }^{6}$ I-III, V (Groningen, 1997-9). Desreumaux's edition is focused more on the codicological aspects, whereas the readings of Müller-Kessler and Sokoloff are on occasion superior.

${ }^{7}$ Christlich-palästinisch-aramä̈sche Texte und Fragmente (Göttingen, 1906) and 'Nachlese christlich-palästinisch-aramäischer Fragmente', ibid, 1955, Nr.5. 
2. Sinai, Georgian ms. $34^{8}$ was also copied by Iovane Zosime, but ten years earlier, in 969, when he was probably still living in the Monastery of St Sabas. Iovane Zosime here made use of re-used folios of at least four different CPA manuscripts, two Gospel mss., a lectionary of the Acts and Epistles, and a hagiographical ms. that includes the Martyrdom of Philemon.

The Georgian ms. was dismembered at some point in the late nineteenth century (probably for the sake of the palimpsest folios), and although 210 folios still remain in St Catherine's Monastery, 51 folios found their way to St Petersburg, and four more to Leipzig. The CPA undertexts of the folios in St Petersburg were published by J.P.N. Land in the fourth volume of his Anecdota Syriaca, and for the most part have been re-read and re-published by C. MüllerKessler and M. Sokoloff in their Corpus of CPA.

The disiecta membra from these two manuscripts, Tsagareli 81 and Sinai Georg. 34, which reached St Petersburg were subsequently bound together as St Petersburg Syr. 16, and the task of separating out these two constituent elements still remains to be properly undertaken. ${ }^{9}$

3. Tsagareli $93+92$ constitute another manuscript which was later removed from the Monastery - though not in its entirety, since 23 folios from it have now turned up among the Georgian 'New Finds' (ms.20). Among the additional folios is the colophon which reveals that the scribe was again Iovane Zosime, this time writing

8 G. Garitte, Catalogue des manuscrits géorgiens littéraires du Mont Sinaï (CSCO 165, Subsidia 9; 1956); M. van Esbroeck, 'Le manuscrit sinaïtique géorgien 34 et les publications récentes de liturgie palestinienne', Orientalia Christiana Periodica 46 (1980), pp.125-41, esp. 129-39, and his article cited in note 5 ..

9 A tentative listing of the different CPA texts in Syr. 16, based on published information, is given in tabular form in my 'Sinai: a meeting point of Georgian with Syriac and Christian Palestinian Aramaic', forthcoming in the Festschrift for Z. Alexidze. It will, of course, be the upper, Georgian, texts which will provide conclusive proof of which folios originally belonged to which of the two Sinai manuscripts. In passing, it might be noted that f.35 (= Land, 'Theol.8') is from Ps. John Chrysostom's Homily on the Prodigal Son, but does not belong to the same ms. as Sinai New Finds Sparagma 7 (ed. in Le Muséon 112 (1999), pp.335-62), whose undertext, with parts of Luke 9 and 17, belongs to the same ms. as Desreumaux's IIB. And St Petersburg Syr. 16, f. 50 belongs to the same ms. as Desreumaux's IIA and 'New Finds' Sparagma 16. 
in 986. Most of the manuscript, however, is divided between three different western libraries, Princeton (Garrett Library ms. 24), ${ }^{10}$ Göttingen (Syr. 19, 23-25) and Birmingham (GB; Mingana Collection, Georgian ms. 4). The CPA undertexts of the folios in Göttingen were published by Duensing, who was able to identify them as containing parts of two texts of Ephraem Graecus (CPG 2925 and 3946). ${ }^{11}$ Duensing evidently had access to some of the folios that are now in Princeton ${ }^{12}$ and it will be interesting to learn if further palimpsest folios are to be found in Garrett 24.

4. All the examples so far adduced have concerned dismembered CPA manuscripts whose text has been erased and the parchment reused in the late tenth century by the Georgian scribe Iovane Zosime. Another Sinai manuscript, Syr. 30, offers an interesting case where the later scribe has made use of folios originating from four separate manuscripts in two different languages. Sinai Syr. 30 is better known simply as the 'Codex Syriacus Sinaiticus', thanks to the 142 palimpsest folios containing the Old Syriac Gospels as the undertext. The upper text, containing Lives of holy women, was copied in Ma'arret Mesrin (north Syria), almost certainly in 779 (and not 698, as is often supposed)..$^{13}$ The Old Syriac Gospel manuscript was by no means the only older manuscript whose parchment the eighth-century scribe re-used, for several other texts from completely different manuscripts have been identified, namely, four folios from the Gospel of John in Greek, 20 folios of the Acts of Thomas in Syriac, four folios with

10 See Garitte, 'Aventures et mésaventures d'un manuscrit géorgien (Le cod. Garrett 24, Princeton)', Bedi Kartlisa 23/24 (1967), pp.37-52; also M. van Esbroeck, 'L'opuscule "Sur la croix" d'Alexandre de Chypre', Bedi Kartlisa 37 (1979), pp.102-32, esp. 103-6.

${ }^{11}$ In his CPA Texte und Fragmente, supplemented by 'Neue christlichpalästinisch-aramäische Fragmente', Nachrichten der Akademie der Wissenschaften in Göttingen, phil.-bist. Kl. 94, nr. 9, and 'Nachlese....'. For a table identifying Duensing's publications of the Göttingen fragments, see my 'Sinai: a meeting point', Table 2.

12 'Neue ... Fragmente', pp.220-1.

13 See my 'Syriac on Sinai: the main connections', in V. Ruggieri and L. Pieralli (eds), Eukosmia. Studi miscellanei per il 750 di Vincenzo Poggi SJ (Soveria Manelli, 2003), pp.103-17, here p.106, note 16. W. Hatch, An Album of Dated Syriac Manuscripts (Boston, 1946), plate XLVI, opted for the earlier date. 
the Transitus of Mary, also in Syriac, ${ }^{14}$ and 12 folios of Ephrem Graecus (in Greek). ${ }^{15}$

Fortunately Sinai Syr. 30 never suffered from dismemberment in modern times - apart from a single folio (f.101), which Agnes Lewis noticed was missing on one of her visits; as a result she put a notice in a biblical periodical ${ }^{16}$ urging the miscreant who had taken it to return it to her, and she would then take it back to the Monastery. Her plea was evidently successful, for the missing folio is now duly back in place.

One other example, again from St Catherine's, might be quoted before turning to some examples of reconstituted manuscripts, both ancient and modern.

5. Alongside the Codex Zosimi Rescriptus (that is, Tsagareli 81) there is another famous Sinai palimpsest manuscript with CPA under-texts, known as the Codex Climaci Rescriptus. This is a manuscript, clearly originating from St Catherine's Monastery, which Agnes Lewis and Margaret Gibson found and bought in Cairo, where it had already been broken up, for they purchased separate parts of it on three different occasions. ${ }^{17}$ The upper text contains the Syriac translation of John of Sinai's Ladder (Klimax, hence the title, Codex Climaci), and a large number of folios turned out to be palimpsests. These re-used folios derive from no less than eight different manuscripts, six in CPA and two in Greek. ${ }^{18}$

${ }^{14}$ A table giving the location in Sinai Syr. 30 of these different undertexts is given by F.C. Burkitt, Evangelion da-Mepharreshe, II (Cambridge, 1904), p.22. The fragments of John and the Acts of Thomas were edited by F.C. Burkitt in A.S. Lewis, Select Narratives of Holy Women (Studia Sinaitica 9 (1900), pp.45-6 and 23-44, respectively; and those of the Transitus Mariae by A.S. Lewis in her Apocrypha Syriaca (Studia Sinaitica 11; 1902), pp.*150-*157 (along with another palimpsest of the same work).

15 Identified as part of Ephrem Graecus, Sermo asceticus (CPG 3909) by S. Voicu, 'Frammenti di un palinsesto greco di Efrem (Sin. syr. 30, f.171 e seguenti)', Scriptorium 38 (1984), pp.77-8.

16 A.S. Lewis, 'A leaf stolen from the Sinai Palimpsest', The Expository Times 13 (1901/2), pp.405-6.

17 A.S. Lewis, Codex Climaci Rescriptus (Horae Semiticae VIII; 1909), pp.xi-xii.

${ }^{18}$ Published in Lewis, Codex Climaci Rescriptus. The CPA biblical texts have now been republished by Müller-Kessler and Sokoloff, in vols I, IIA and IIB of their Corpus of CPA, while the Greek Gospel text (Gregory, 
In the course of breaking up the manuscript, a single folio had got separated, and this was eventually purchased, along with other stray folios originating from St Catherine's Monastery, by Alphonse Mingana (with funds from the Cadbury Trust) for the Mingana Collection in Birmingham (Mingana Syr. 637); this folio too was palimpsest, and the CPA under-text was duly published by M. Black. ${ }^{19}$ The rest of the manuscript, as purchased by Agnes Lewis and Margaret Gibson, was left by them at their deaths to Westminster College, Cambridge; in 2009, however, the College put the manuscript on sale at Sotheby's (London) where it was sold to an American buyer. ${ }^{20}$ The original ownership of the manuscript by St Catherine's Monastery is now conclusively shown by the presence among the Syriac 'New Finds' (M38N) of a further eight folios (constituting quire 18) of the manuscript; the illustration in Mother Philothée's catalogue ${ }^{21}$ indicates that at least that folio is also a palimpsest with a CPA under-text. ${ }^{22}$

The rather impressive number of palimpsests that feature among the Syriac manuscripts of St Catherine's Monastery provide many other examples of ktabe mpassqe whose parchment has been re-used. Likewise many other examples of manuscripts which have suffered a similar fate in both ancient and modern times could be adduced. ${ }^{23}$

\section{RECONSTITUTED MANUSCRIPTS: 1, IN ANTIQUITY}

A small number of medieval Gospel manuscripts exist which have been pieced together out of several different earlier manuscripts

1561 L) has been studied in detail by I.A. Moir, 'Codex Climaci Rescriptus Graecus' (Cambridge, 1956); Moir also re-published the two Septuagint under-texts (Rahlfs 839, Joshua; and 2011, Pss.), 'Two Septuagint palimpsests', Journal of Theological Studies ns 8 (1957), pp.1-11 (for these, see also D. Fraenkel, Verzeichnis der griechischen Handschriften des Alten Testaments, I.1 [Göttingen, 2004], pp.53-4).

19 M. Black, 'A Palestinian Syriac palimpsest leaf of Acts xxi, 14-16', Bulletin of the John Rylands Library (Manchester) 23 (1939), pp.1-16.

${ }^{20} \mathrm{~S}$. Green, for his Bible Museum.

21 Philothée du Sinai,Nouveaux manuscrits syriaques du Sinaï (Athens, 2008), p.422.

22 Mingana Syr. 637 belongs immediately before M38N.

23 A few further ones will be found in the final paragraphs, concerning some modern reconstitutions of ktabe mpassqe. 
which may be of very different date and style of script. In a few cases folios from one of the earlier manuscripts may turn up in two different reconstituted manuscripts. All four of the 'reconstituted' manuscripts described below originally belonged (in one case, still belongs) to the library of Dayr al-Suryan.

1. British Library, Add. 12,137 (Wright, Catalogue, I, pp.50-52; no. LXXV), contains the Four Gospels, but the manuscript is in fact a composite one, having been put together out of four different earlier manuscripts by a recluse who identifies himself as 'Samuel the stranger, known as a recluse in Gozarta in the land of Egypt'; he goes on to state that he had collected together 'from Egypt' and bound 'this holy book', and that 'it belongs to the Monastery of the Bearer of God (i.e. Dayr al-Suryan) in the desert of Abba Makarios'. According to Wright, his 'rude Estrangela' hand belongs to the late $11^{\text {th }}$ century. The four different parchment manuscripts he put together were:

A. ff.2-177; Four Gospels, up to John 6:52; 2 columns (of 2225 lines), $6^{\text {th }} / 7^{\text {th }}$ cent. Samuel has supplied the missing text of a lacuna in Matthew (10:10-26) on a paper fill (f.19).

B. ff.178, 179, 186, with John 6:35-7:2 and 10:3-20; 2 columns (of 23-25 lines), $6^{\text {th }}$ cent. The missing text has been supplied by Samuel on ff.180-5 (paper).

C. ff.187-207, with John 10:20-19:29; 2 columns (of 22-24 lines), $6^{\text {th }}$ cent.

D. ff.212-3, with John 21:12 - end; 2 columns (of 23-24 lines), $8^{\text {th }}$ cent. A colophon indicates that this manuscript did not include Mark. ${ }^{24}$ The missing text between $\mathrm{C}$ and $\mathrm{D}$ has again been supplied on paper (ff.208-11), presumably by Samuel, who adds a note identifying himself on $\mathrm{f} .213 \mathrm{v} . .^{25}$

2. British Library, Add. 12,141 (Wright, Catalogue, pp.63-4; no. LXXXIX), contains Matthew, John and Luke (in that order), built

${ }^{24}$ A tenth-century hand states that the manuscript belongs to Dayr al-Suryan,

25 This Samuel is evidently the same person as the Samuel bar Quryaqos who wrote Add. 14,490 (Lectionary, dated 1089) and Add.17,127 (Commentary on Revelation, dated 1088), for both of which he re-used a Syriac translation of works by Galen and the fifth-century Iatrosophist Gesios; according to Wright, Catalogue, p.161, Samuel also provided palimpsest fills to two more Lectionaries, Add. 14,486 and 14,487. (See also for Samuel Wright's index, Catalogue, p. 1319). 
up out of three different manuscripts, with some gaps filled by the person who put them together.

A. ff.1-87, with Matthew (beginning 1:13) and John 21:12; 2 columns (of 23-28 lines), $6^{\text {th }} / 7^{\text {th }}$ cent. There is now lacuna in Matthew (6:19-7:5), while those in Luke have been supplied from manuscripts $\mathrm{B}$ and $\mathrm{C}$.

B. ff.88, 94, with Luke 1:1-19 and 4:22-40; 2 columns (of 24-26 lines), $8^{\text {th }}$ cent. According to Wright, this belongs to the same manuscript that supplied part D in Add. 12,137. The missing text between these two folios has been supplied (on parchment) on ff.89-93 in 'an inelegant Estrangela' of the 11th cent.

C. ff.95-144, 146-8, with Luke 4:40-23:34, and 23:51 - end (less the last four words); 2 columns (of 22-26 lines), $6^{\text {th }}$ cent. According to Wright, this belongs to the same manuscript that supplied part C in Add. 12,137. The missing text in chapter 23 has been supplied by the compiler on f.145. (A folio, containing Luke 9:58-10:13, has been lost after f.110). Although the compiler's hand is similar to that of Samuel in Add. 12,137, it is probably not his.

3. Berlin, Orient.quart.528 (Sachau, Verzeichnis, p.17, no.8), contains the four Gospels (incomplete), built up out of four different manuscripts (one of which, D, was the Curetonian ms. of the Old Syriac Gospels).

A. ff.2-11, and 56-126, with Matthew 1:1 - 10:21, Mark 14: 58 end, Luke and John; 2 columns (of 29-31 lines), $8^{\text {th }}$ cent. At the end of John a later hand has added a note indicating that the manuscript belongs to Dayr al-Suryan.

B. ff.12-17, and 42-55 (several folios are badly damaged), with Matthew 9:29-10:6, 10:21-12:22, 13:24-14:22, Mark 5:30-14:58, 15:4-13; Luke 13:4-16:2, and 19:7-21:23; 1 column (of 35-38 lines), East Syriac hand of $9^{\text {th }}$ cent. According to Sachau, this part belongs to the same manuscript as ff.38-56 of British Library, Add. 14669 (Wright, Catalogue, p.58); as will be seen below, the same manuscript has been drawn upon to supply parts of Dayr al-Suryan ms. 11, another composite Gospel ms.

C. ff..18-41, with Matthew 18:1 - 28:4; 2 columns (of 24 lines), $6^{\text {th }}$ cent.

D. ff.1, 128 and 129 (serving as protective beginning and end leaves): Luke 15:22-16:12 , 17:1-23, and John 7:37-52 + 8:12-19; 2 columns (of 23-25 lines), $5^{\text {th }}$ cent. These three folios belong to the 'Curetonian' ms. of the Old Syriac Gospels (Add. 14,451), and the 
gap between f.1 and f.128 is now filled by a folio of the same ms. still in Dayr al-Suryan (Fragment 9). ${ }^{26}$

4. Dayr al-Suryan Syriac ms.11. This incomplete Gospel ms. (7 quires have been lost at the beginning) has been pieced together out of no less than six different earlier mss.

A. ff.1-68, with Mark 9:10 - Luke 22:42; 2 columns (of c. 26 lines), 5 th $/ 6^{\text {th }}$ cent. bold estrangelo.

B. ff. 69-74, with Luke 22:42 - 24:52; 2 columns (of c.25 lines), $8^{\text {th }}$ cent. estrangelo.

C. ff.75-77, 79-88, 92-96, 102-3, with Luke 24:53 - John 2:5, $2: 23-6: 34,7: 38-9: 26,20: 17-21: 12 ; 2$ columns (of c.25 lines), $5^{\text {th }} / 6^{\text {th }}$ cent. estrangelo.

D. f.78, with John 2:5-22; 1 column (of 18-19 lines), late hand imitating estrangelo, $13^{\text {th }} / 14^{\text {th }}$ cent. The folio is palimpsest with a CPA under-text (Psalms). Probably it was the scribe of this folio who put the whole manuscript together.

E. ff.89, 97-101, with Luke 5:35 - 6:46; John 13:3 - 20:24; 1 column (of 35 lines), East Syriac estrangelo, 9th cent. Dayr alSuryan Syriac Fragment 10 (with Luke 8:39 - 9:30) also belongs to the same manuscript, as do ff.38-56 of British Library, Add. 14, 669 (with fragments of all four Gospels, ${ }^{27}$ including the passages on either side of Luke 5:35-6:46), and Berlin, Orient. quart. 528, section $\mathrm{B}$ (see above, under 3).

F. ff.90-91, with John 6:1 - 7:51; 1 column (of 39 lines), estrangelo, $8^{\text {th }}$ cent.

G. f.104, with John 21:12 - end; 2 columns (of 26 lines), estrangelo, $6^{\text {th }}$ cent. A colophon indicates that the manuscript originally contained Matthew and John.

Not surprisingly, several joins are unsatisfactory, in that either there is a gap of a few words between two consecutive parts, or there is an overlap (in which case there may be an indication that the extra text in one of the two parts should be deleted).

\section{RECONSTITUTED MANUSCRIPTS: 2, IN MODERN TIMES}

With the assistance of modern technology and digital imaging it is now possible to reconstitute in virtual form the ktabe mpassqe whose

${ }^{26}$ Published by D. McConnaughy. 'A recently discovered folio of the Old Syriac (Sy-c) text of Luke 16:13-17:1', Biblica 68 (1987), pp.85-88.

${ }^{27}$ Listed in Wright, Catalogue, p.58. 
dismemberment goes back to unscrupulous manuscript collectors of the $19^{\text {th }}$ and early $20^{\text {th }}$ centuries. So far this has only been done with the famous Greek Codex Sinaiticus, ${ }^{28}$ most of which is in the British Library (Add. 43,725), but of which 43 folios are in Leipzig while a further 12 folios and a number of fragments still remain in St Catherine's Monastery, having turned up among the 'New Finds'.

Obviously it would be highly desirable to do the same thing for the many other ktabe mpassqe which once existed in a complete form in the Monastery of St Catherine (or elsewhere) ${ }^{29}$; a prior task, however, needs to be undertaken of locating and piecing together all the memba disiecta of these manuscripts, now scattered over the entire world. Much initial work of this sort has indeed already been undertaken, in particular by P. Géhin. ${ }^{30}$ Here it will be sufficient to draw attention to a few examples that, for one reason or another, are of particular interest.

1. Sinai Syr. 52 contains the earlier of the two Syriac translations of the influential corpus of texts attributed to Dionysius the Areopagite ('Ps. Dionysius'); the translation was very probably the work of Sergius of Resh'aina (d.536), who provided it with the preface that is transmitted in the same manuscript. In its present form Sinai Syr. 52 is missing a number of folios, both at the beginning (including the whole of Sergius' Preface) and at the end. The opening of Sergius' Preface ${ }^{31}$ now turns out to be still in the

${ }^{28}$ D.C. Parker (ed.), Codex Sinaiticus, Facsimile Edition (London, 2011); http://www.codexsinaiticus.org.

${ }^{29}$ One thinks here especially of the fate of the Coptic manuscripts from the White Monastery.

30 See his articles cited in notes 32, 33, 39, below. For a preliminary list of fragments from Sinai in the Mingana Collection (Birmingham), see my 'Mingana syr. 628: a folio from a revision of the Peshitta Song of Songs', Journal of Semitic Studies 40 (1995), pp.39-56, with Appendix 'Mingana Syriac fragments from Sinai', pp.51-3. See also my 'The Syriac "New Finds" at St Catherine's Monastery, Sinai, and their significance', The Harp (forthcoming).

31 The Preface also circulated independently, having been attached to Phokas' later translation of the corpus; it was from different mss. of this provenance that P. Sherwood edited and translated the text in L'Orient Syrien 5 and 6 (1960, 1961); for his mss. (ultimately going back to an edition of Phokas by Kyriakos bar Shammuni, dated 766/7), see L'Orient Syrien 5 (1960), pp.434-7. 
Monastery, for it has been identified among the Syriac 'New Finds' (M81N), while a few, very damaged, fragments from the Letters (which come at the end of the work), have also turned up among the Syriac Fragments of the 'New Finds' (Sparagma 37). Other folios, however, had disappeared from the monastery some time around the beginning of the $20^{\text {th }}$ century, and it has only been recently that these have been identified: more of Sergius' Preface from the Sinai manuscript, and the beginning of the translation of the Divine Names, was identified independently by I. Perczel and M. Quaschning-Kirsch as being part VI (13 folios) of the different old fragments that are now bound up as Paris Syr. 378.32 A further folio from Sergius' Preface is now in Milan (f. 86 of the fragments from Sinai, acquired in 1910, and now bound as Ambrosianus A 296 inf.), the identification having been made by Géhin. ${ }^{33}$

2. The incomplete Sinai Syr. 24 is an eighth or ninth-century manuscript with the 'First Part' of Isaac of Nineveh's Discourses. Its real interest did not emerge until Géhin identified another part of Paris Syr. 378 (IX; ff.61-8) as containing the initial quire of Sinai Syr.24; at the beginning of this it is specifically stated that the manuscript was written in the Monastery of St Sabas, in Palestine. ${ }^{34}$ The significance of this immediately becomes clear when one recalls that the Greek translation of much of the First Part was made by two monks, Abramios and Patrikios, of the Monastery of St Sabas, and that they must have been working at some time around the late eighth century, since the earliest Greek manuscript

32 I. Perczel first announced the identification at a conference, and subsequently published it in the course of an article in the Revue des études augustiniennes 45 (1999), p.81, note 3; the identification was likewise made by M. Quaschning-Kirsch, 'Ein weiterer Textzeuge für die syrische Version des Corpus Dionysiacum Areopagitum: Paris B.N. syr. 378', Le Muséon 113 (2000), 115-24. See also Géhin, 'Manuscrits sinaitiques dispersés, I. les fragments syriaques et arabes de Paris', Oriens Christianus 90 (2006), pp.23-43; here, 37-8. (The content of Paris Syr. 278 VI had earlier been identified by F. Nau, in Revue de l'Orient Chrétien III.7 (1929/30), p.414, but without linking it with Sinai syr. 52).

33 'Manuscrits sinaitiques dispersés II: les fragments théologiques syriaques de Milan (Chabot 34-57)', Oriens Christianus 91 (2007), pp.1-24, here p.21.

${ }^{34}$ Géhin, 'Manuscrits sinaïtiques dispersés, I', p.40. 
is dated to the ninth century. ${ }^{35} \mathrm{~A}$ further eight folios from the same manuscript have been identified by Géhin among the Milan fragments from Sinai. ${ }^{36}$

3. It was a sad fate that almost the whole of the earliest manuscript in any language known to have been specifically written for St Catherine's Monastery was taken from the Monastery in the late nineteenth century. Most of the manuscript was acquired in Cairo in 1895 for the library in Strasbourg (now ms. 4116), and it was the work contained in this ms., the Book of Perfection by the early seventh-century monastic author Sahdona (Martyrius) that Paul Bedjan published in 1902. A quarter of a century later the colophon, containing the date and provenance of the manuscript was published by N. Pigulevskaya from the two folios of the manuscript in the Leningrad (St Petersburg) Public Library: this revealed that the manuscript had been written in 'the Christ-loving and blessed Edessa', where the scribe had completed it on Thursday, 16 th March 837. It had been written for the monk Anba Sargi, who had then donated it to 'Beth Mar Mushe on the Holy Mountain of Sinai'. Subsequently further folios, scattered around European libraries, have been identified: one folio, among the Milan fragments, was identified by A. de Halleux in time to include in his re-edition, in the CSCO, ${ }^{37}$ of this important work. Since then, two folios in the Mingana Collection (Birmingham) and another folio among the Milan fragments have been identified as belonging to this manuscript. ${ }^{38}$ Happily it now turns out that a certain number of folios from this manuscript still remain in St Catherine's, where

35 K. Treu, 'Remnants of a majuscule codex of Isaac Syrus from Damascus', Studia Patristica 16 = Texte und Untersuchungen 129 (1985), pp.114-20.

36 A 296 inf, ff.122-9; 'Géhin, Manuscrits sinaïtiques dispersés II', p.5.

37 A. de Halleux, Martyrius (Sahdona), Oeuvres spirituels, I-V (CSCO 200201, 214-5, 252-5; 1960-1965).

38 For the Mingana fragment (Syr.. 650) see my 'A further fragment of the Sinai Sahdona manuscript', Le Muséon 81 (1968), pp.139-54 (with text and translation); and for the further Milan fragment (f.87), P. Géhin, 'Manuscrits sinaïtiques dispersés, II', p.19; his edition with French translation is now published in F. Briquel Chatonnet and M. Debié (eds), Sur les pas des Araméens chrétiens. Mélanges offerts à Alain Desreumaux (Cahiers d'Études syriaques 1; Paris, 2010), pp.195-205. 
they have been catalogued as M45N in Mother Philothée's catalogue of the Syriac 'New Finds'.39

4. Sinai Syr. 19, of the $8^{\text {th }}$ cent ${ }^{40}$ contains the Syriac translation of Gregory of Nyssa's Commentary on the Song of Songs, ${ }^{41}$ a work that was to have considerable influence on the subsequent Syriac liturgical tradition. It had long been known that parts of the same manuscript had found their illicit way to various western libraries, ${ }^{42}$ but the identification of further folios among the 'New Finds' (M53N and Sparagma 23) has revealed that, in its original form, the manuscript also contained the Syriac translation of Hippolytus' Against Gaius, a work whose Greek original is lost. ${ }^{43}$ Hitherto this work by Hippolytus had only been known from quotations in Dionysius bar Salibi's Commentary on the Apocalypse.

Many further examples of the identification of 'joins' between Sinai manuscripts and their membra disiecta could be adduced, and certainly further work of this sort needs to be undertaken before any reliable reconstitutions, in some virtual form, of these ktabe mpassqe can be satisfactorily carried out. In the case of those manuscripts originating from Dayr al-Suryan, which are today in the Vatican and British Library, the catalogue of those manuscripts and fragments remaining at the Monastery ${ }^{44}$ will bring to light a considerable number of joins with those now in the British Library.

39 Philothée du Sinai, Nouveaux manuscrits syriaques du Sinä̈, pp.474-8: 'Homélies, Instructions'. For the identification, see my 'New fragments of Sahdona's Book of Perfection at St Catherine's Monastery, Mount Sinai', Orientalia Christiana Periodica 75 (2009), pp.175-8, and (independently) P. Géhin, 'Manuscrits patristiques syriaques des Nouvelles découvertes du Sinaï, Collectanea Christiana Orientalia 6 (2009), 67-93, here p.83.

40 This is the date usually given; my ' $6^{\text {th }}$ cent.' for Sparagma 23 is probably rather too early (as is Mother Philothée's '5th cent.'), though Géhin has adopted it in his recent 'Fragments patristiques', p.84.

41 The manuscript was the subject of a fine study by C. van den Eynde, La version syriaque du commentaire de Grégoire de Nysse sur le Cantique des cantiques (Louvain, 1939).

42 Leipzig Or. 1078, olim Zurich 76, Milan A 296 inf. ff.191-4, and Birmingham, Mingana Syr. 628; for details see Géhin, 'Manuscrits sinaïtiques dispersés II, pp.8-9.

43 For its significance, see A. Camplani and E. Prinzivalli, 'Sul significato dei nuovi frammenti siriaci dei Capitula adversus Caium attribuiti a Ippolto', Augustinianum 38 (1998), pp.49-82.

${ }^{44}$ By L. van Rompay and S.P. Brock (forthcoming). 